\title{
Can a simple fall cause a rotator cuff tear? Literature review and biomechanical considerations
}

\author{
Richard W. Nyffeler ${ }^{1,2}$ (D) N Nicholas Schenk ${ }^{1,3}$ (D) Philipp Bissig ${ }^{1}$ (i) \\ Received: 24 January 2021 / Accepted: 16 March 2021 / Published online: 27 March 2021 \\ (C) The Author(s) 2021
}

\begin{abstract}
Purpose A simple fall on the shoulder is often referred to as minor trauma that cannot cause a tendon tear but at best reveal a preexisting rotator cuff pathology. We wanted to know whether this statement was true. The purpose of our study was therefore to summarize the causes of acute rotator cuff tears reported in the literature and provide a biomechanical explanation for tendon tears diagnosed after a fall.

Method We searched PubMed and included studies reporting rotator cuff tears occurring due to a trauma. The number of cases, the tendons involved, the age of the patients, and the nature of trauma were summarized. In addition, we noted any information provided by the authors on the pathogenesis of acute tendon ruptures.

Results Sixty-seven articles with a total of 4061 traumatic rotator cuff tears met the inclusion criteria. A simple fall was the most common cause ( 725 cases) and the supraspinatus tendon was most frequently affected. The postulated pathomechanism is a sudden stretch of the tendon-muscle unit while contracting (eccentric loading).

Conclusion A simple fall can cause an acute rotator cuff tear and fall-related tears are not restricted to young individuals. They can affect patients of any age. The stresses occurring within the rotator cuff during an attempt to cushion a fall may locally exceed the tensile strength of the tendon fibers and cause a partial or full-thickness tear.
\end{abstract}

Keywords Shoulder $\cdot$ Trauma $\cdot$ Injury $\cdot$ Fall $\cdot$ Rotator cuff tear

\section{Introduction}

Rotator cuff tear (RCT) is a common cause of shoulder pain and dysfunction in patients older than 50 years of age. The prevalence increases with age [1-4], the aetiology, however, is still under debate. Many authors hold the opinion that the majority of tendon tears are the result of age-related degenerative changes [5]. Accordingly, research has focused on this area and numerous intrinsic and extrinsic factors for tendon degeneration have been postulated in the last decades. Accident-related research has not been advanced to the same extent, although more than 80 years ago, some eminent

Richard W. Nyffeler

richard.nyffeler@bluewin.ch

1 Orthopädie Sonnenhof, Salvisbergstrasse 4, 3006 Bern, Switzerland

2 Stiftung Lindenhof, Campus SLB, Swiss Institute for Translational and Entrepreneurial Medicine, Freiburgstrasse 3, 3010 Bern, Switzerland

3 Praxis Integri, Hirschengraben 7, 3011 Bern, Switzerland scientists reported that, in addition to age-related tissue changes, a definite injury is required for a full-thickness RCT [6-8].

The assessment of whether a tendon lesion is traumatic or degenerative in nature is not only important to determine the type of treatment required and expected outcome [9-15], but also in applying the appropriate insurance cover. In many countries, the benefits of accident insurances are more comprehensive than those of health insurances. Due to the high prevalence of RCTs in the elderly population, as well as the major economic burden they pose, accident insurance companies are very critical of accident-related tendon tears. Certain experts [16-18] have maintained for many years that a fall onto the outstretched arm or the shoulder cannot cause an RCT, but will only result in a contusion. They argued that the deltoid muscle covers and protects the rotator cuff, that the scapula can deflect and absorb the energy, and that the tensile strength of the rotator cuff tendons is three times higher than the maximum force the muscles can generate. They also purport that most RCTs, which are diagnosed on MRI after a fall, are pre-existing due to degenerative changes or overuse (Fig. 1). Courts often uphold insurance experts, even if the patients had not experienced any previous shoulder complaints and had never consulted their family 


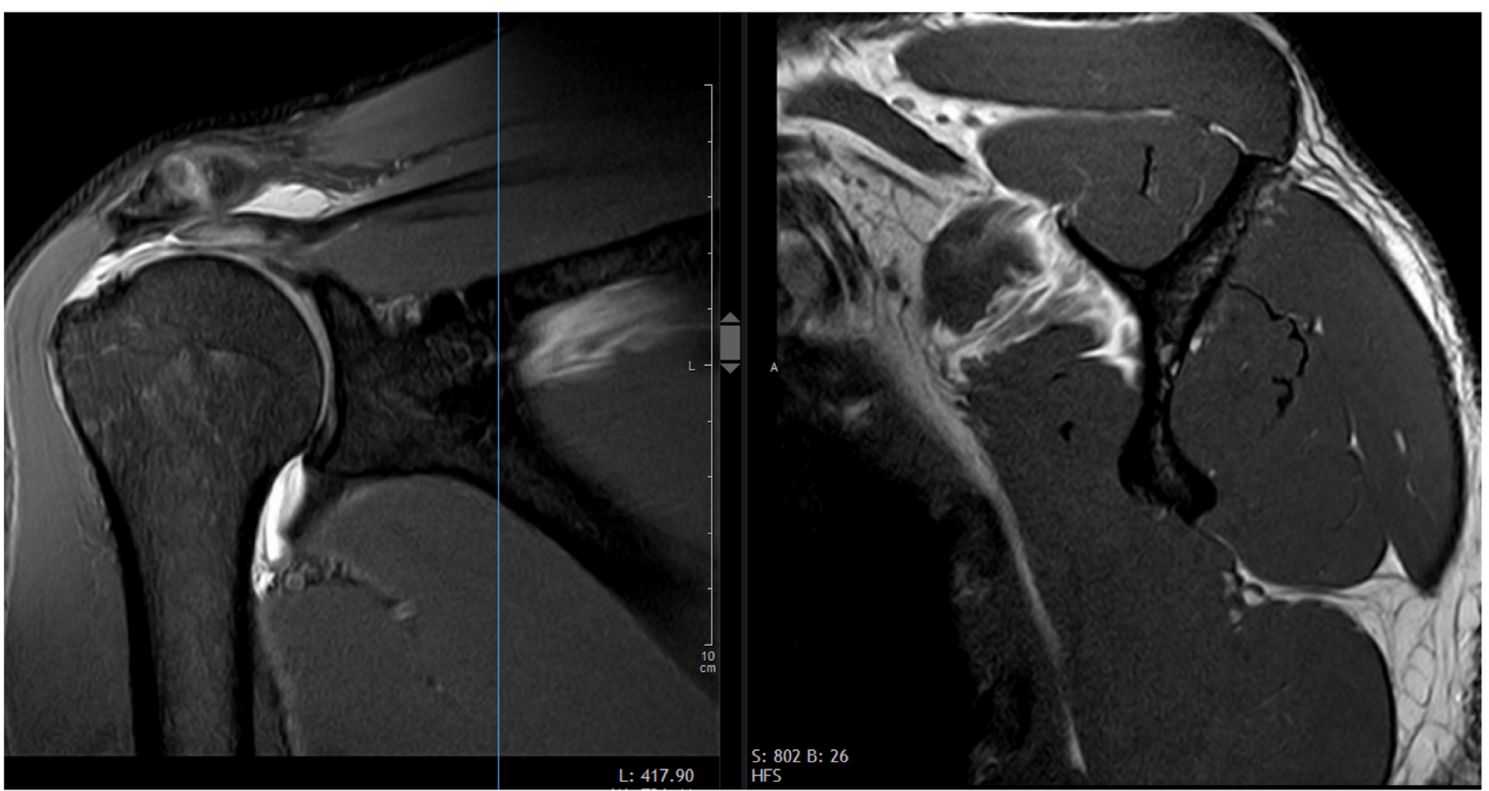

Fig. 1 Coronal and sagittal MR images of the right shoulder of a 37-yearold man showing a full-thickness supraspinatus tendon tear. The examination was made seven weeks after a fall on the shoulder following a header duel during a football match. Despite the young age, immediate

doctor for shoulder problems prior to the accident. The purpose of the present study was therefore to review the literature on acute and traumatic RCTs, summarize the nature of trauma, and provide a biomechanical explanation for the tendon tears caused by falls.

\section{Materials and methods}

We conducted a literature search of PubMed up to September 30, 2020, using the terms "acute rotator cuff tear," "traumatic rotator cuff tear," and "fall AND rotator cuff tear." This yielded 450 results after exclusion of duplicates. The title and abstract of each result were examined. Animal studies, cadaver studies, technical reports, case reports, review articles, and studies without acute or traumatic tears were excluded. The full texts of eligible articles were screened, and the following information was extracted: authors, year of publication, study design (retrospective versus prospective), number and age of patients included, number or percentage of traumatic tendon tears, affected tendons and causes.

\section{Results}

Sixty-seven articles with a total of 10,796 shoulders met the inclusion criteria. They are listed chronologically in Table 1. Most studies were retrospective. Eighteen studies included only traumatic tears. The others included also patients with non-traumatic tears, other pathologies, or healthy individuals pain, initial pseudoparesis, and normal muscle trophics, the insurance expert claimed that the accident had only caused a contusion and that the tendon was already torn before the event

in a control group. Overall, 4061 RCTs were attributed to trauma. The following causes were reported in descending order of frequency: fall (725), shoulder dislocation (577), violent pull or sudden traction injury (296), sports injury (145), blow, direct trauma or impact to the shoulder (103), vehicle accident (97), hyperextension, forced abduction and external rotation or grabbing a rail to prevent falling (88), and lifting heavy objects or catching a falling object (29). The mechanism of injury in traffic accidents, sports injuries, and the causes of shoulder dislocations were not always specified. It can be assumed that a considerable number of them were the result of a fall [56]. In 2001 cases, the nature of trauma was not clear or not reported. The supraspinatus was by far the most frequently affected tendon. Bigger tears also involved the infraspinatus and or subscapularis tendon. Isolated tears of the subscapularis tendon were also reported. The age of patients with fall-related RCTs ranged from 15 to 89 years [66].

Only few authors proposed a pathomechanism of traumatic supraspinatus tears. Lindblom [8] and Matsen [78] noted that falls on the outstretched hand or elbow are followed by a forced adduction of the arm in the scapulohumeral joint. Walcott et al. [71] hypothesized that a fall onto the abducted arm results in an axial load that forces the supraspinatus tendon into the lateral acromion, causing a transtendinous tear.

\section{Discussion}

The primary finding of this literature review is that a substantial number of RCTs have been associated with a traumatic 


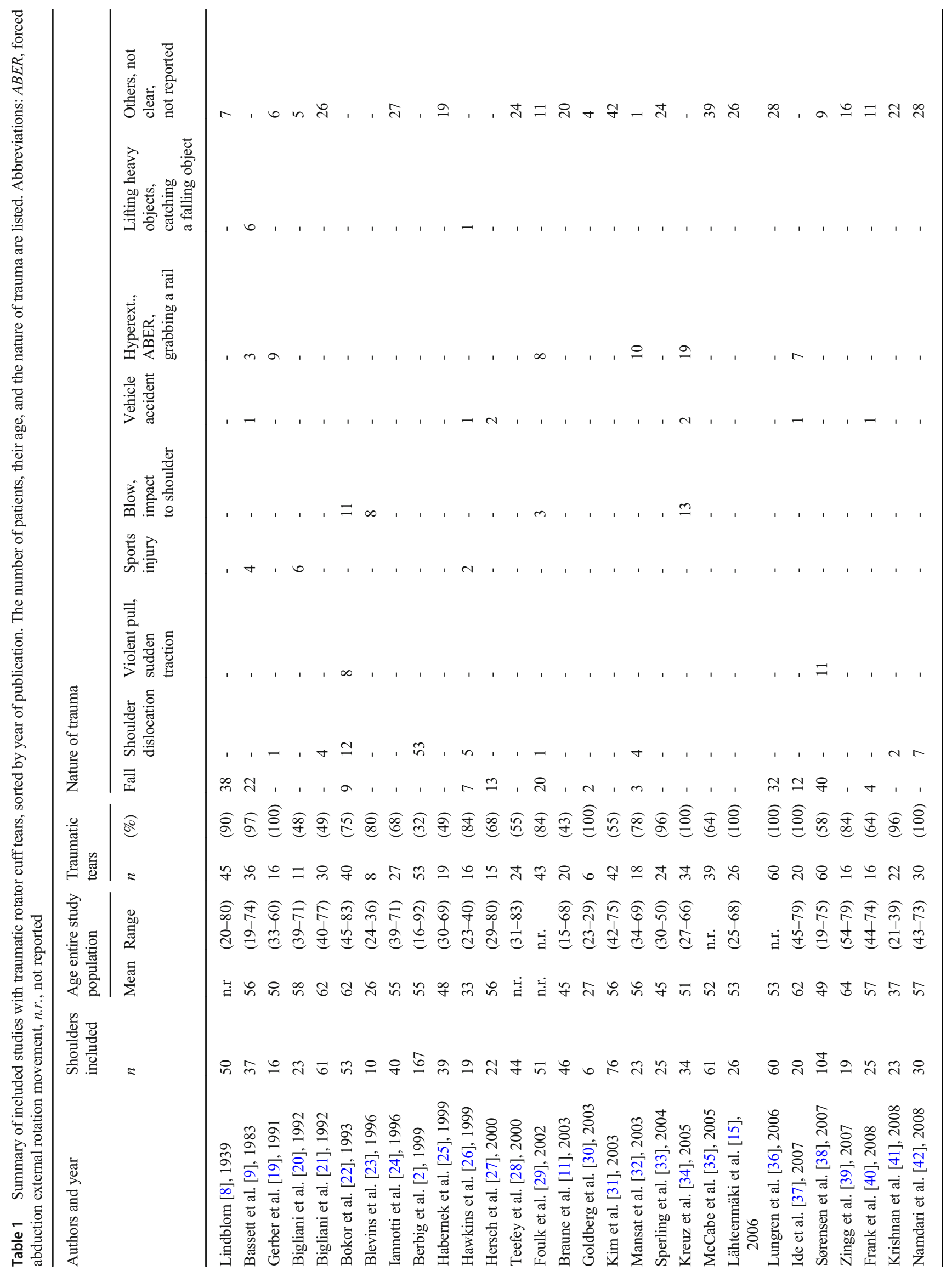




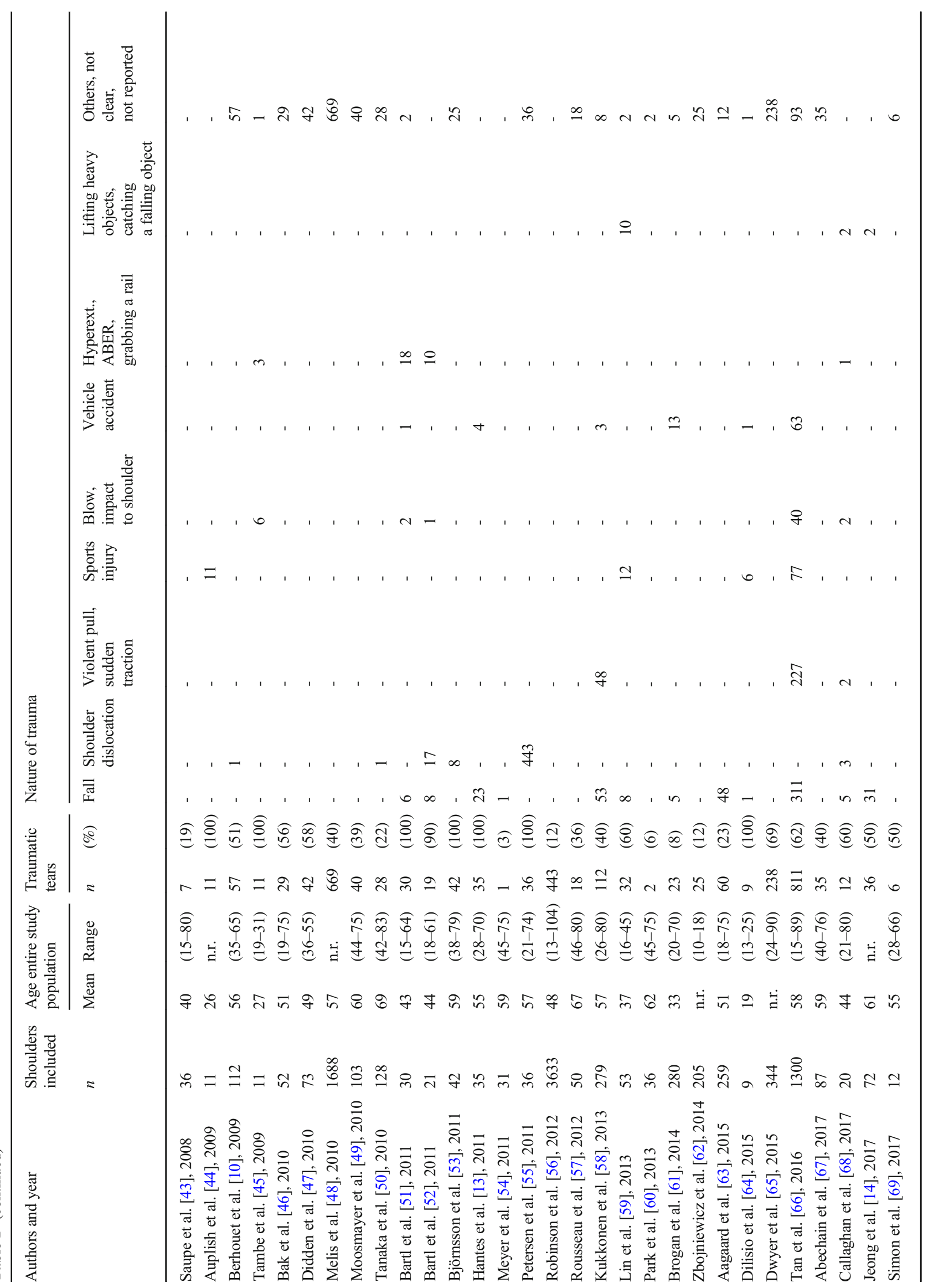




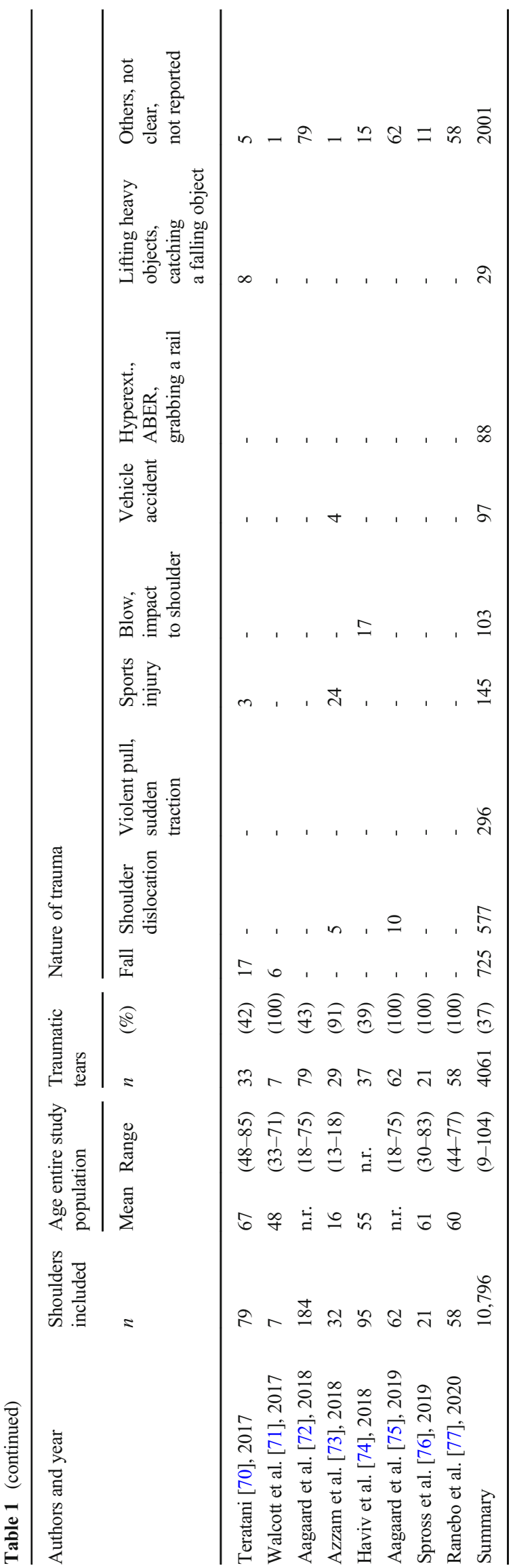

event. In the study by Tan et al. [66] including only patients with RCTs, the percentage of traumatic tendon tears was $62 \%$, and in the study by Melis et al. [48], it was $40 \%$. A history of trauma was also a risk factor for RCT in a large epidemiologic study on the prevalence of RCTs in the general population [4]. We found 26 articles that had associated RCTs with a fall (Table 1). Tan [66] reported 311, Kukkonen et al. [58] 53, Aagaard et al. [63] 48, and Lungren et al. [36] 32 RCTs after a fall. Foulk et al. [29] identified 51 professional athletes with RCTs and stated that the most common mechanism of injury was a fall. This statement is consistent with the findings of Mall et al. [79].

Persons who slip or trip do not simply let themselves fall. By moving their arms, they try to find their balance again or reach for nearby support, such as a hand rail [80-82]. If the fall cannot be avoided, the arms are used as a protective measure to soften the impact on the ground and prevent injuries to the hips, shoulder, and head [83-85]. In the study by Lungren et al. [36], most falls were to the side and front. Accordingly, the arm impacting the ground may either be forced to the side $[8,77]$ or pushed away, resulting in an adduction and internal rotation or abduction and external rotation of the shoulder respectively (Fig. 2). In the first case, the supra- and infraspinatus tendons are most significantly stressed. In the second case, the subscapularis tendon and the rotator interval are subjected to heavy loads.

Several authors consider a fall as minor trauma [16-18, 24, 44]. This is not justified, as most fractures of the hip, the wrist, the olecranon, the humeral head, and the clavicle occur as a result of a simple fall. The forces occurring on impact may be considerable. Sabick et al. [86] simulated side falls from a kneeling position onto a force platform covered with foam. The peak impact force at the shoulder attained 3 times bodyweight (BW) when the subjects fell with the body tensed and 2.5 times BW when they attempted to break the fall by using an arm. Under the latter test condition, the peak force at the hand/arm was significantly greater than the force at either the hip or shoulder and averaged $3.78 \mathrm{BW}$. In a similar fall simulation using anthropomorphic test dummies, the peak impact force on the shoulder ranged from 3.2 to 10.1 times BW [87]. Naturally, the forces are expected to be much higher when falling from a standing or walking position [88, 89]. In vivo experiments with living people are not possible because of the risk of injury. Chiu and Robinovitch [89] therefore developed a computer model to predict the body's impact response during forward falls from heights between 0 and $2 \mathrm{~m}$ and obtained a peak impact force on the hands of as much as $4.2 \mathrm{kN}$.

The forces occurring in the rotator cuff were not determined in these studies. The dynamic aspect of a fall, the numerous impact possibilities, and the energy absorption by the different tissues make the calculation of these forces very difficult. However, it is possible to determine the forces required 
Fig. 2 Drawings of a typical fall. The subject attempts to avoid to hit the floor with his face and uses the arms to attenuate the impact on the ground. Most falls are to the side (a), loading the posterosuperior rotator cuff or the front (b), loading the anterosuperior rotator cuff
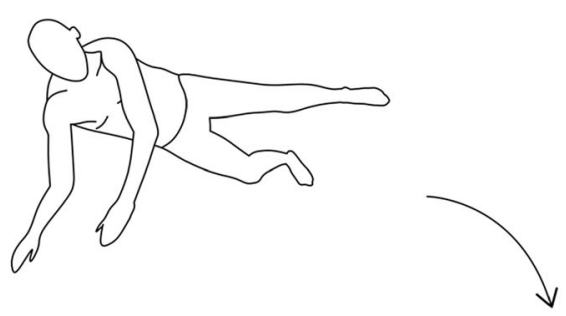

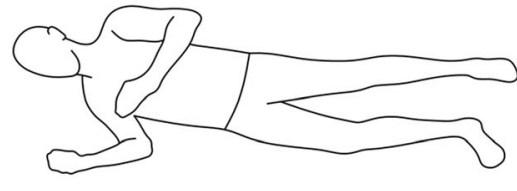

a

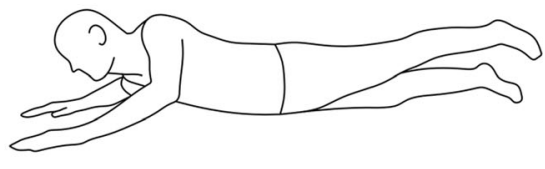

b to maintain the body in a lateral plank position. The lateral plank (or lateral abdominal bridge) is an isometric exercise to strengthen the oblique abdominal muscles and the entire core. The body is tensed and only the elbow, forearm, hand, and the lateral aspect of the foot are in contact with the ground. The supporting upper arm is almost perpendicular to the body axis (Fig. 3a). In this position, the ground force under the elbow is about $0.64 \mathrm{BW}$ and is transmitted directly to the glenohumeral joint. The moment in the shoulder to maintain balance is small. The ground force $\mathrm{F} 1(\alpha)$ and the moment $\mathrm{M}(\alpha)$ increase as the abduction angle of the arm becomes smaller (Fig. $3 b$ and Fig. 4). They can be determined with trigonometry and

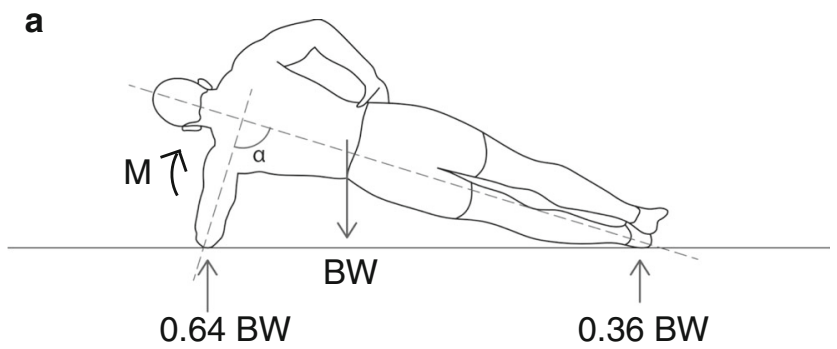

b

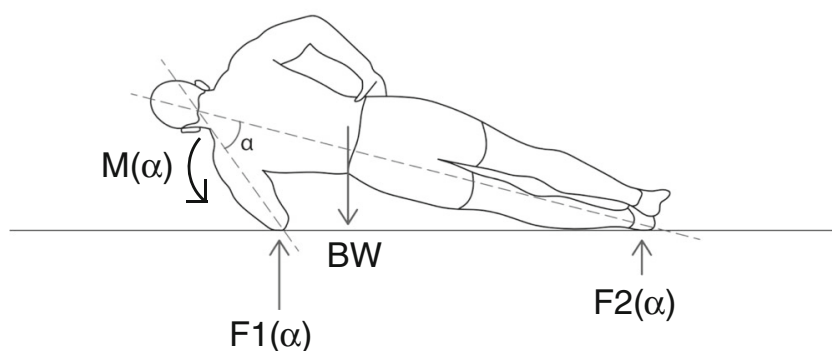

Fig. 3 Illustration of the lateral plank exercise. When the arm is abducted $90^{\circ}$, the force under the elbow is about 0.64 body weight and directed to the shoulder. The moment in the shoulder is small and the body can be kept in balance. When the arm is brought against the body, the ground reaction force under the elbow $\mathrm{F} 1(\alpha)$ increases slightly, the lever arm and the moment $\mathrm{M}(\alpha)$ in the shoulder to maintain balance, however, increase rapidly with the equilibrium conditions. The maximum torque that the shoulder muscles can generate under isometric conditions has been determined by several researchers and varies between 18.5 and $61.7 \mathrm{Nm}$ [90-92]. Accordingly, it is impossible for most people to keep the body in balance if the arm is spread $60^{\circ}$ or less. When trying to slow down a fall, the peak forces at the elbow and the moment in the shoulder are even greater than under static conditions. When the moment exceeds the torque produced by the muscles, the arm is forced to the side and the posterosuperior rotator cuff tendon-muscle unit is lengthened while contracting. The sudden increase in stress may induce muscle damage and tendon lesions. That it is possible to tear a tendon with one's own muscle strength can be observed with distal biceps tendon avulsions, quadriceps tendon lesions, and Achilles tendon ruptures. In all of these cases, the mechanism of injury is a sudden and high eccentric loading of the musculotendinous unit.

The mechanism of tendon rupture in vivo differs greatly from a monoaxial tensile test conducted in a laboratory. In vivo not all muscle and tendon fibres are equally stretched and stressed [93]. During eccentric contractions, the weakest elements will absorb most of the length change and may disrupt first [94]. The load is then distributed to the adjacent elements, which may in turn be overloaded and disrupt $[8,95]$. The force needed to tear each fibre individually is much smaller than the force needed to tear all fibres simultaneously. Men who rip a phonebook in half with their bare hands take advantage of this feature (Video https://www.youtube.com/watch? $\mathrm{v}=$ k3yvxuMGwCg). Pre-existing alterations of the mechanical properties of the tendon tissue, such as altered gliding properties between tendon fibrils, may decrease its resistance $[8,95,96]$.

The damage caused by a fall depends on many factors. These include, amongst others, the speed, height, weight, defense strategy, direction of impact, muscle strength, and tissue quality. It is conceivable that people who actively resist a fall are more likely to tear a tendon, while people who fall freely are more likely to suffer a humeral head fracture. The age of patients sustaining fall-related RCTs ranged from 15 to 89 
abduction moment $\mathrm{M}(\alpha)$ necessary to maintain the lateral plank $(\mathrm{Nm})$

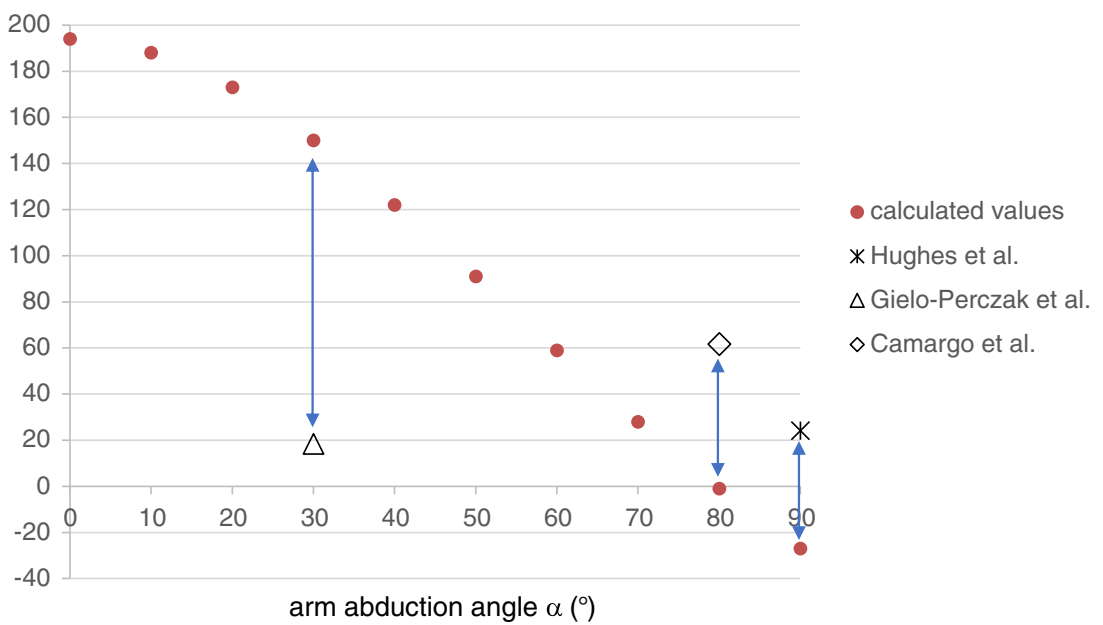

Fig. 4 Graph representing the moment $\mathrm{M}(\alpha)$ that the shoulder muscles must generate to keep a person weighing $84 \mathrm{~kg}$ in the lateral plank position as a function of the abduction angle $(\alpha)$ of the arm (red dots). The maximum moment that the shoulder muscles of healthy volunteers can generate is taken from previous studies and represented with separate

[66] years. This highlights two important points: Firstly, the forces occurring during a fall can be so great that even a tendon of a young and healthy individual without degenerative changes can tear. Secondly, traumatic tears are not limited to young adults. Due to the greater risk of falling and the poorer tendon quality, the risk of traumatic tendon rupture is even higher in the elderly population [36].

Because most people fall one or more times during their lives, it is conceivable that many of the tendon tears classified as degenerative have been instigated by a fall and have been missed or trivialized at the time of the accident [38]. Zbojniewicz et al. [62] reviewed 205 MRI or MR arthrograms of children and adolescents at a large pediatric hospital and identified 25 RCTs. The majority were articular-side partialthickness tears and treated non-surgically. As most RCTs do not heal spontaneously but enlarge over time, they may become symptomatic again years later when the patient no longer remembers the accident that originally weakened the tendon.

Our literature search does not claim to be complete. We have limited ourselves to the PubMed database and the terms "acute rotator cuff tear," "traumatic rotator cuff tear," and "fall AND rotator cuff tear." Therefore, it is possible that numerous other studies reported fall-related tendon injuries that are not include in our review. Further cases and more consistent reporting of causes [97] would add to the evidence but would not change the fact that tendon ruptures can occur following a fall.

\section{Conclusion}

Many clinical studies and biomechanical considerations confirm that a fall can cause an acute RCT and that fall-related tears are not marks. At an abduction angle of about $60^{\circ}$ or less, the moment necessary to stabilize the body exceeds the moment that the shoulder muscles can generate and the arm is forced to the side, resulting in an eccentric loading of the rotator cuff and an impact of the shoulder on the ground

restricted to young individuals. They can affect patients of any age. The forces and stresses occurring in the rotator cuff during an attempt to cushion a fall may locally exceed the tensile strength of the tendon fibres and cause a partial or full-thickness RCT.

Acknowledgements The authors would like to thank Florence Nyffeler for the drawings.

Author contribution RW Nyffeler designed the study, performed the literature search, collected data and wrote the manuscript. P Bissig and $\mathrm{N}$ Schenk contributed to data collection and revised the manuscript critically for intellectual content.

Data availability No supplementary material is submitted.

\section{Declarations}

Ethics approval and consent to participate Ethics approval was not necessary for the submitted literature review. The patient whose MR images are shown in Fig. 1 consented to participate.

Consent to publish The patient whose MR images are shown in Fig. 1 consented to publication.

Competing interests The authors declare no competing interests.

Open Access This article is licensed under a Creative Commons Attribution 4.0 International License, which permits use, sharing, adaptation, distribution and reproduction in any medium or format, as long as you give appropriate credit to the original author(s) and the source, provide a link to the Creative Commons licence, and indicate if changes were made. The images or other third party material in this article are included in the article's Creative Commons licence, unless indicated otherwise in a credit line to the material. If material is not included in the article's Creative Commons licence and your intended use is not permitted by statutory regulation or exceeds the permitted use, you will need to obtain 
permission directly from the copyright holder. To view a copy of this licence, visit http://creativecommons.org/licenses/by/4.0/.

\section{References}

1. Milgrom C, Schaffler M, Gilbert S, van Holsbeeck M (1975) Rotator-cuff changes in asymptomatic adults. J Bone Joint Surg (Br) 77-B:296-298

2. Berbig R, Weishaupt D, Prim J, Shahin O (1999) Primary anterior shoulder dislocation and rotator cuff tears. J Shoulder Elb Surg 8: 220-225

3. Moosmayer S, Smith HJ, Tariq R et al (2009) Prevalence and characteristics of asymptomatic tears of the rotator cuff: an ultrasonographic and clinical study. J Bone Joint Surg (Br) 91:196-200

4. Yamamoto A, Takagishi K, Osawa T, Yanagwa T, Nakajima D, Shitara H, Kobayashi T (2010) J Shoulder Elb Surg 19:116-120

5. Hashimoto T, Nobuhara K, Hamada T (2003) Pathologic evidence of degeneration as a primary cause of rotator cuff tear. Clin Orthop Related Research 415:111-120

6. Codman EA (1934) Rupture of the supraspinatus tendon. In: The shoulder. Thomas Todd, Boston

7. Watson-Jones R (1938) Injuries in the region of the shoulder joint. The British Medical Journal July 2:29-32

8. Lindblom K (1939) On pathogenesis of ruptures of the tendon aponeurosis of the shoulder joint. Acta Radiol 20:563-577

9. Bassett RW, Cofield RH (1983) Acute tears of the rotator cuff. The timing of surgical repair. Clin Orthop Relat Res 175:18-24

10. Berhouet J, Collin P, Benkalfate T, Le Du C, Duparc F, Courage O, Favard L (2009) Massive rotator cuff tears in patients younger than 65 years. Epidemiology and characteristics. Orthop Traumatol Surg Res 95(Suppl 1):13-18

11. Braune C, von Eisenhart-Rothe R, Welsch F, Teufel M, Jaeger A (2003) Mid-term results and quantitative comparison of postoperative shoulder function in traumatic and non-traumatic rotator cuff tears. Arch Orthop Trauma Surg 123:419-424

12. Boileau P, Brassard N, Watkinson DJ, Carles M, Hatzidakis AM, Krishnan SG (2005) Arthroscopic repair of full-thickness tears of the supraspinatus: does the tendon really heal? J Bone Joint Surg Am 87:1229-1240

13. Hantes ME, Karidakis GK, Vlychou M, Varitimidis S, Dailiana Z, Malizos KN (2011) A comparison of early versus delayed repair of traumatic rotator cuff tears. Knee Surg Sports Traumatol Arthrosc 19:1766-1770

14. Jeong JY, Song SY, Yoo JC, Park KM, Lee SM (2017) Comparison of outcomes with arthroscopic repair of acute-onchronic within 6 months and chronic rotator cuff tears. J Shoulder Elb Surg 26:648-655

15. Lähteenmäki HE, Virolainen P, Hiltunen A, Heikkilä J, Nelimarkka OI (2006) Results of early operative treatment of rotator cuff tears with acute symptoms. J Shoulder Elb Surg 15:148-153

16. Bonnaire F (2008) Begutachtung der Rotatorenmanschettenläsion. Trauma Berufskrankh 10(Suppl 1):16-24

17. Ludolph E (2008) Begutachtung der Zusammenhangstrennung der Rotatorenmanschette. Trauma Berufskrankh 10(Suppl 3):316-318

18. Hempfling H, Wich M (2018) Begutachtung des Rotatorenschadens. Trauma Berufskrankh 20:121-133

19. Gerber C, Krushell RJ (1991) Isolated rupture of the tendon of the subscapularis muscle. Clinical features in 16 cases. J Bone Joint Surg Br 73:389-394

20. Bigliani LU, Cordasco FA, McIveen SJ, Musso ES (1992) Operative repair of massive rotator cuff tears: long-term results. J Shoulder Elb Surg 13:120-130
21. Bigliani LU, Kimmel J, McCann PD, Wolfe I (1992) Repair of rotator cuff tears in tennis players. Am J Sports Med 20:112-117

22. Bokor DJ, Hawkins RJ, Huckell GH, Angelo RL, Schickendantz MS (1993) Results of nonoperative management of full-thickness tears of the rotator cuff. Clin Orthop Relat Res 294:103-110

23. Blevins FT, Hayes WM, Warren RF (1996) Rotator cuff injury in contact athletes. Am J Sports Med 24:263-267

24. Iannotti JP, Bernot MP, Kuhlman JR, Kelley MJ, Williams GR (1996) Postoperative assessment of shoulder function: a prospective study of full-thickness rotator cuff tears. J Shoulder Elb Surg 5: 449-457

25. Habernek H, Schmid L, Frauenschuh E (1999) Five year results of rotator cuff repair. Br J Sports Med 33:430-433

26. Hawkins RJ, Morin WD, Bonutti PM (1999) Surgical treatment of full-thickness rotator cuff tears in patients 40 years of age or younger. J Shoulder Elb Surg 8:259-265

27. Hersch JC, Sgaglione NA (2000) Arthroscopically assisted miniopen rotator cuff repairs. Functional outcome at 2- to 7-year followup. Am J Sports Med 28:301-311

28. Teefey SA, Middleton WD, Bauer GS, Hildebolt CF, Yamaguchi K (2000) Sonographic differences in the appearance of acute and chronic full-thickness rotator cuff tears. J Ultrasound Med 19: 377-381

29. Foulk DA, Darmelio MP, Rettig AC, Misamore G (2002) Fullthickness rotator-cuff tears in professional football players. Am J Orthop (Belle Mead NJ) 31:622-624

30. Goldberg JA, Chan KY, Best JP, Bruce WJM, Walsh W, Parry W (2003) Surgical management of large rotator cuff tears combined with instability in elite rugby football players. Br J Sports Med 37: 179-181

31. Kim SH, Ha KI, Park JH, Kang JS, Oh SK, Oh I (2003) Arthroscopic versus mini-open salvage repair of the rotator cuff tear: outcome analysis at 2 to 6 years' follow-up. Arthroscopy 19: 746-754

32. Mansat P, Frankle MA, Cofield RH (2003) Tears in the subscapularis tendon: descriptive analysis and results of surgical repair. Joint Bone Spine 70:342-347

33. Sperling JW, Cofield RH, Schleck C (2004) Rotator cuff repair in patients fifty years of age or younger. J Bone Joint Surg Am 86: 2212-2215

34. Kreuz PC, Remiger A, Erggelet C, Hinterwimmer S, Niemeyer P, Gächter A (2005) Isolated and combined tears of the subscapularis tendon. Am J Sports Med 33:1831-1837

35. McCabe RA, Nicholas SJ, Montgomery KD, Finneran JF, McHugh MP (2005) The effect of rotator cuff tear size on shoulder strength and range of motion. J Orthop Sports Ther 35:130-135

36. Lungren M, Smith D, Carpenter JE, Hughes RE (2006) Fall-related rotator cuff tears. J Musculoskelet Res 10:75-81

37. Ide J, Tokiyoshi A, Hirose J, Mizuta H (2007) Arthroscopic repair of traumatic combined rotator cuff tears involving the subscapularis tendon. J Bone Joint Surg Am 89:2378-2388

38. Sørensen AKB, Bak K, Krarup AL, Thune CH, Nygaard M, Jorgensen U, Sloth C, Torp-Pedersen S (2007) Acute rotator cuff tear: do we miss the early diagnosis? A prospective study showing a high incidence of rotator cuff tears after shoulder trauma. J Shoulder Elb Surg 16:174-180

39. Zingg PO, Jost B, Sukthankar A, Bühler M, Pfirrmann CWA, Gerber C (2007) Clinical and structural outcomes of nonoperative management of massive rotator cuff tears. J Bone Joint Surg Am 89:1928-1934

40. Frank JB, ElAttrache NS, Dines JS, Blackburn A, Crues J, Tibone JE (2008) Repair site integrity after arthroscopic transosseousequivalent suture-bridge rotator cuff repair. Am J Sports Med 36: 1496-1503

41. Krishnan SG, Harkins DC, Schiffern SC, Pennington SD, Burkhead WZ (2008) Arthroscopic repair of full-thickness tears 
of the rotator cuff in patents younger than 40 years. Arthroscopy 24:324-328

42. Namdari S, Henn RF 3rd, Green A (2008) Traumatic anterosuperior rotator cuff tears: the outcome of open surgical repair. J Bone Joint Surg Am 90:1906-1913

43. Saupe N, White LM, Bleakney R, Schweizer ME, Recht MP, Jost B, Zanetti M (2008) Acute traumatic posterior shoulder dislocation: MR findings. Radiology 248:185.193

44. Auplish S, Funk L (2009) Rotator cuff tears in athletes. Br J Hosp Med (Lond) 70:271-275

45. Tambe A, Badge R, Funk L (2009) Arthroscopic rotator cuff repair in elite rugby players. Int J Shoulder Surg 3:8-12

46. Bak K, Sørensen AK, Jørgensen U, Nygaard M, Krarup AL, Thune C, Sloth C, Pedersen ST (2010) The value of clinical tests in acute full-thickness tears of the supraspinatus tendon: does a subacromial lidocaine injection help in the clinical diagnosis? A prospective. Arthroscopy 26:734-742

47. Didden K, Leirs G, Aerts P (2010) The impact of the Belgian workers' compensation system on return to work after rotator cuff surgery. Acta Orthop Belg 76:592-597

48. Melis B, DeFranco MJ, Chuinard C, Walch G (2010) Natural history of fatty infiltration and atrophy of the supraspinatus muscle in rotator cuff tears. Clin Orthop Relat Res 468:1498-1505

49. Moosmayer S, Lund G, Seljom U, Svege I, Henning T, Tariq R, Smith HJ (2010) Comparison between surgery and physiotherapy in the treatment of small and medium-sized tears of the rotator cuff. J Bone Joint Surg Br 92:83-91

50. Tanaka M, Itoi E, Sato K, Hamada J, Hitachi S, Tojo Y, Honda M, Tabata S (2010) Factors related to successful outcome of conservative treatment for rotator cuff tears. Ups J Med Sci 115:193-200

51. Bartl C, Salzmann GM, Seppel G, Eichhorn S, Holzapfel K, Wörtler K, Imhof AB (2011) Subscapularis function and structural integrity after arthroscopic repair of isolated subscapularis tears. Am J Sports Med 39:1255-1262

52. Bartl C, Scheibel M, Magosch P, Lichtenberg S, Habermeyer P (2011) Open repair of isolated traumatic subscapularis tendon tears. Am J Sports Med 39:490-496

53. Björnsson HC, Norlin R, Johansson K, Adolfsson LE (2011) The influence of age, delay of repair, and tendon involvement in acute rotator cuff tears: structural and clinical outcomes after repair of 42 shoulders. Acta Orthop 82:187-192

54. Meyer M, Klouche S, Rousselin B, Boru B, Bauer T, Hardy P (2011) Does arthroscopic rotator cuff repair actually heal? Anatomic evaluation with magnetic resonance arthrography at minimum 2 years follow-up. J Shoulder Elb Surg 21:531-536

55. Petersen SA, Murphy TP (2011) The timing of rotator cuff repair for the restoration of function. J Shoulder Elb Surg 20:62-68

56. Robinson CM, Shur N, Sharpe T, Ray A, Murray IR (2012) Injuries associated with traumatic anterior glenohumeral dislocations. J Bone Joint Surg Am 94:18-26

57. Rousseau T, Roussignol X, Bertiaux S, Duparc F, Dujardin F, Courage O (2012) Arthroscopic repair of large and massive rotator cuff tears using the side-to-side suture technique. Mid-term clinical and anatomic evaluation. Orthop Traumatol Surg Res 98(4 Suppl): S1-S8

58. Kukkonen J, Joukainen A, Äärimaa V (2013) Operatively treated traumatic versus non-traumatic rotator cuff ruptures: a registry study. Ups J Med Sci 118:29-34

59. Lin EC, Mall NA, Dhawan A, Sherman SL, McGill KC, Provencher MT, Nicholson GP, Cole BJ, Solomon DJ, Verma NN, Romeo AA (2013) Arthroscopic primary rotator cuff repairs in patients aged younger than 45 years. Arthroscopy 29:811-817

60. Park JY, Lhee SH, Oh KS, Moon SG, Hwang JT (2013) Clinical and ultrasonographic outcomes of arthroscopic suture bridge repair for massive rotator cuff tear. Arthroscopy 29:280-289
61. Brogan DM, Carofino BC, Kircher MF, Spinner RJ, Elhassan BT, Bishop AT, Shin A (2014) Prevalence of rotator cuff tears in adults with traumatic brachial plexus injuries. J Bone Joint Surg Am 96(16):e139

62. Zbojniewicz AM, Maeder ME, Emery KH, Salisbury SR (2014) Rotator cuff tears in children and adolescents: experience at a large pediatric hospital. Pediatr Radiol 44:729-737

63. Aagaard KE, Abu-Zidan F, Lunsjo K (2015) High incidence of acute full-thickness rotator cuff tears: a population-based prospective study in a Swedish community. Acta Orthop 86:558-5562

64. Dilisio MF, Noel CR, Noble JS, Bell RH (2015) Traumatic supraspinatus tears in patients younger than 25 years. Orthopedics 38:e631-e634

65. Dwyer T, Razmjou H, Holtby R (2015) Full-thickness rotator cuff tears in patients younger than 55 years: clinical outcome of arthroscopic repair in comparison with older patients. Knee Surg Sorts Traumatol Arthrosc 23:508-513

66. Tan M, Lam PH, Le BTN, Murrell GAC (2016) Trauma versus no trauma: an analysis of the effect of tear mechanism on tendon healing in 1300 consecutive patients after arthroscopic rotator cuff repair. J Shoulder Elb Surg 25:12-21

67. Abechain JJK, Gomes Godinho G, Matsunaga FT, Archetti Netto N, Pozzetti Daou J, Sugawara Tamaoki MJ (2017) Functional outcomes of traumatic and non-traumatic rotator cuff tears after arthroscopic repair. World J Orthop 8:631-637

68. Callaghan MJ, Baombe JP, Horner D, Hutchinson CE, Sandher D, Carley S (2017) A prospective, observational cohort study of patients presenting to an emergency department with acute shoulder trauma: the Manchester emergency shoulder (MESH) project. BMC Emergency Medicine 17(1):40

69. Simon M, Popp D, Lutter C, Schöffl V (2017) Functional and sports-specific outcome after surgical repair of rotator cuff tears in rock climbers. Wilderness Environ Med 28:342-347

70. Teratani $\mathrm{T}$ (2017) Comparison of the epidemiology and outcomes of traumatic and nontraumatic rotator cuff tears. J Orthop 14:166170

71. Walcott ME, Daniels SD, Sinz NJ, Field LD, Higgins LD (2017) Traumatic full-thickness transtendinous rotator cuff tears: a case series. J Shoulder Elb Surg 26:62-67

72. Aagaard KE, Hänninen J, Abu-Zidan FM, Lunsjö K (2018) Physical therapists as first-line diagnosticians for traumatic acute rotator cuff tears: a prospective study. Eur J Trauma Emerg Surg 44(5):735-745

73. Azzam MG, Dugas JR, Andrews JR, Goldstein SR, Emblom BA, Cain EL Jr (2018) Rotator cuff repair in adolescent athletes. Am J Sports Med 46(5):1084-1090

74. Haviv B, Rutenberg TF, Bronak S, Yassin M (2018) Arthroscopic rotator cuff surgery following shoulder trauma improves outcome despite additional pathologies and slow recovery. Knee Surgery Sports Traumatology Arthroscopy 26:3804-3809

75. Aagaard KE, Lunsjö K, Frobell R (2019) Early repair of traumarelated full-thickness rotator cuff tears does not eliminate the problem of healing failure. Bone Joint J 101-B:603-609

76. Spross C, Behrens G, Dietrich TJ, Kim CHO, Puskas GJ, Zdravkovic V, Jost B (2019) Early arthroscopic repair of acute traumatic massive rotator cuff tears leads to reliable reversal of pseudoparesis: clinical and radiographic outcome. Arthroscopy 35:343-350

77. Ranebo MC, Björnsson Hallgren HC, Holmgren T, Adolfsson LE (2020) Surgery and physiotherapy were both successful in the treatment of small, acute, traumatic rotator cuff tears: a prospective randomized trial. J Shoulder Elb Surg 29:459-470

78. Matsen FA III (2008) Rotator-cuff failure. N Engl J Med 358:2138 2147

79. Mall NA, Lee AS, Chahal J, Sherman SL, Romeo AA, Verma NN, Cole BJ (2013) An evidence-based examination of the 
epidemiology and outcomes of traumatic rotator cuff tears. Arthroscopy 29:366-376

80. Roos PE, McGuigan MP, Kerwin DG, Trewartha G (2008) The role of arm movement in early trip recovery in younger and older adults. Gait Posture 27:352-362

81. Merrill Z, Chambers AJ, Cham R (2017) Arm reactions in response to an unexpected slip - impact of aging. J Biomech 58:21-26

82. Lattimer LJ, Lanovaz JL, Farthing JP, Madill S, Kim S, Arnold C (2016) Upper limb and trunk muscle activation during an unexpected descent on the outstretched hands in young and older women. $\mathrm{J}$ Electromyogr Kinesiol 30:231-237

83. DeGoede KM, Ashton-Miller JA (2002) Fall arrest strategy affects peak hand impact force in a forward fall. J Biomech 35:843-848

84. Lo J, Ashton-Miller JA (2008) Effect of pre-impact movement strategies in the impact forces resulting from a lateral fall. $\mathrm{J}$ Biomech 41:1969-1977

85. Mazeas J, Traulle M, Acco M, Solignac N, Forelli F (2020) Role of deltoid muscle in reducing peak forces in forward fall simulation. Int J Ortho Res 3:111-115

86. Sabick MB, Ha JG, Goel VK, Banks SA (1999) Active responses decrease impact forces at the hip and shoulder in falls to the side. $\mathrm{J}$ Biomech 32:993-998

87. Thor CP, Bieryla K, Gabler C (2008) Estimating shoulder injury risk using low rate lateral impacts to dummies. Biomed Sci Instrum 44:274-279

88. Chou PH, Chou YL, Lin CJ, Su FC, Lou SZ, Lin CF, Huang GF (2001) Effect of elbow flexion on upper extremity impact forces during a fall. Clin Biomech 16:888-894

89. Chiu J, Robinovitch N (1998) Prediction of upper extremity impact forces during falls on the outstretched hand. J Biomech 31:11691176
90. Hughes RE, An KN (1996) Force analysis of rotator cuff muscles. Clin Orthop Rel Res 330:75-83

91. Gielo-Perczak K, Matz S, An KN (2006) Arm abduction strength and its relationship to shoulder geometry. J Electromyogr Kinesiol 16:66-78

92. Camargo PR, Avila MA, de Oliveira AB, Asso NA (2009) Shoulder abduction torque steadiness is preserved in subacromial impingement syndrome. Eur J Appl Physiol 106:381-387

93. Lake SP, Miller KS, Elliott DM, Soslowsky LJ (2009) Effect of fiber distribution and realignment on the nonlinear and inhomogeneous mechanical properties of human supraspinatus tendon under longitudinal tensile loading. JOR:1596-1602

94. Proske U, Morgan DL (2001) Muscle damage from eccentric exercise: mechanism, mechanical signs, adaptation and clinical applications. J Physiol 537:333-345

95. Nyffeler RW, Meyer DC (2017) Acromion and glenoid shape: why are they important predictive factors for the future of our shoulders? EFORT Open Rev 2:141-150

96. Sano H, Ishii H, Yeadon A, Backman DS, Brunet JA, Uhthoff HK (1997) Degeneration at the insertion weakens the tensile strength of the supraspinatus tendon: a comparative mechanical and histologic study of the bone-tendon complex. JOR

97. Pogorzelski J, Erber B, Themessl A, Rupp MC, Feucht MJ, Imhoff AB, Degenhardt A, Irger A (2021) Definition of the terms "acute" and "traumatic" in rotator cuff injuries: a systematic review and call for standardization in nomenclature. Arch Orthop Trauma Surg 141:75-91

Publisher's note Springer Nature remains neutral with regard to jurisdictional claims in published maps and institutional affiliations. 